\title{
PENGARUH PEMBERIAN EKSTRAK BIJI JINTEN HITAM (Nigella sativa) TERHADAP KADAR GSH, MDA, JUMLAH SERTA FUNGSI SEL MAKROFAG ALVEOLAR PARU TIKUS WISTAR YANG DIPAPAR ASAP ROKOK KRONIS
}

\section{THE EFFECT OF BLACK SEED CRUDE EXTRACT (Nigella sativa) ON GSH AND MDA LEVEL, NUMBER AND FUNCTION OF LUNG ALVEOLAR MACROPHAGE OF WISTAR RAT WHICH EXPOSED BY CHRONIC CIGARETTE SMOKE}

\author{
Marwan*, Edi Widjajanto **, Setyawati Karyono *** \\ * Laboratorium Anatomi Histologi Program Pendidikan Dokter Universitas Mulawarman Samarinda \\ ** Laboratorium Patologi Klinik Fakultas Kedokteran Universitas Brawijaya Malang \\ *** Laboratorium Farmakolgi Fakultas Kedokteran Universitas Brawijaya Malang
}

\begin{abstract}
Cigarette smoke is the main risk factor of chronic obstructive pulmonary disease (COPD). Several studies about COPD has focused on the oxidative stress in lung. Oxidative stress was related to inactivation of antiprotease enzymes, airway epithelial destruction and proinflammatory genes expression. Antioxidant may useful for treatment of COPD. Black seed (Nigela sativa) studies have showed that black seed has antioxidant activity. The aim of this research was to prove that black seed crude extract can protect wistar rat lung from oxidative stress which was caused by chronic cigarette smoke exposure. This experimental research used randomized complete design with control group. Thirty wistar strain of Rattus novergicus, 2.5 to 3 months old, 150 - 250 grams of weight were divided into five groups. First group was used as negative control group (without any treatment), second group as positive control group (only cigarette smoke exposure treatment), third group as cigarette smoke exposure and black seed crude extract dose $0.6 \mathrm{gr} / \mathrm{kilogram}$ of body weight/day (group A), cigarette smoke exposure and black seed crude extract dose 1.2 gr/kilogram of body weight/day (group B) and cigarette smoke exposure and black seed crude extract dose $2.4 \mathrm{gr} / \mathrm{kilogram}$ of body weight/day (group C). After 3 months five parameters were measured in this research. They were GSH and MDA of level lung tissue, number and phagocytosis function also reactive oxygen intermediate (ROI) secretion of alveolar macrophage. All data from five parameters in this study were analyzed by the Tukey HSD test and one way anova. MDA level of group C was $0.40900 \pm$ $0.256992 \mathrm{nmol} / \mathrm{gr}$. wet tissue, significantly lower than positive control group. GSH level of group C was $1.31450 \pm$ $0.035707 \mu \mathrm{mol} / \mathrm{gr}$. wet tissue, not significantly higher than positive control group. The number of alveolar macrophage from group $C$ significantly lower than positive control group, phagocytosis function and $R O I$ secretion function from alveolar macrophage were significantly lower than the positive control group $(p<0.05)$. The crude extract of black seed can protect wistar rat lung from oxidative stress which is caused by chronic cigarette smoke exposure.
\end{abstract}

Key words: black seed crude extract, GSH, MDA, Reactive oxygen intermediate, phagocytosis

\section{PENDAHULUAN}

Penelitian tentang penyakit paru obstruktif menahun (PPOM) serta penanganannya dewasa ini banyak terfokus pada ketidakseimbangan oksidan-antioksidan. Hal ini disebabkan ditemukannya peningkatan petanda-petanda stres oksidatif di dalam darah, urine maupun saluran nafas perdertia PPOM dan para perokok. Hal lain yang ditemukan adalah stres oksidatif berperan penting dalam patogenesa PPOM. Kondisi stres oksidatif berkaitan dengan inaktivasi enzim-enzim antiprotease, kerusakan epithel saluran nafas, peningkatan sekuestrasi netrofil di mikrovaskuler pulmonal serta ekspresi gen-gen proinflamasi $(1,2,3)$.

Jurnal Kedokteran Brawijaya, Vol. XXI, No.3, Desember 2005

Korespondensi: Marwan; Laboratorium Anatomi Histologi

Fakultas Kedokteran Unmul Samarinda, Kalimantan Timur
Asap rokok mengandung $10^{14}$ molekul radikal bebas dalam setiap hisapnya. Selain itu, asap rokok juga mengandung bahan-bahan hydroquinone/quinone, akrolein, asetaldehide dan formalin yang dapat memicu radikal bebas ataupun melemahkan antioksidan yang ada di dalam tubuh (4). Penelitian yang dilakukan oleh Aoshiba (2003) yang menyebutkan bahwa paparan asap rokok akut menyebabkan penurunan kadar gluthatione (GSH) paru, penurunan aktivitas gluthatione peroksidase dan glucose 6 phosphate dehydrogenase (G6PD) (5). Sebaliknya, paparan asap rokok kronis menyebabkan peningkatan kadar GSH serta aktivitas enzim-enzim tersebut. Tetapi, peningkatan tersebut tidak adekuat melindungi sel-sel di paru terhadap paparan asap rokok kronis tersebut. Peningkatan kadar GSH yang terjadi pada paparan asap rokok kronis tersebut merupakan mekanisme adaptasi terhadap stres oksidatif. 
Penelitian yang dilakukan Subandi (1998) tentang pengaruh paparan asap rokok kronis, juga menunjukkan hasil yang sejalan. Pada penelitian tersebut terjadi penurunan antioksidan enzimatis yang lain, yaitu penurunan kadar SOD (superoxide dismutase) jaringan paru tikus (6).

Penelitian ilmiah yang telah dilakukan menunjukkan adanya potensi antioksidan di dalam biji jinten hitam. Burits dan Bucar (2000) dengan menggunakan metode kromatografi lapis tipis dua dimensi menemukan bahwa komponen di dalam jinten hitam mempunyai kemampuan $\mathrm{OH}$ radical scavenging yang efektif pada peroksidasi lipid nonenzimatis dan degradasi deoxyribose (7).

Houghton dkk (1995) dalam penelitiannya mendapatkan hasil bahwa thymoquinone yang dikandung oleh jinten hitam mempunyai kemampuan menghambat peroksidasi nonenzimatis pada fosfolipid liposom otak sapi jantan (8). Percobaan lain dilakukan oleh El Dakhakhny (2000) tentang fungsi protektif jinten hitam pada sekresi ulkus gaster tikus yang diinduksi oleh ethanol, didapatkan hasil adanya peningkatan signifikan kadar gluthatione serta penurunan kadar histamin di dalam sekresi gasternya pada kelompok yang diberi jinten hitam (9).

Melihat potensi antioksidan di dalam biji jinten hitam tersebut, maka pada penelitian ini akan diuji potensi antioksidan biji jinten hitam tersebut dalam mencegah terjadinya stres oksidatif di paru tikus akibat paparan asap rokok kronis. Parameter yang dinilai adalah kadar GSH dan MDA jaringan paru, jumlah dan fungsi fagositosis serta fungsi sekresi ROI makrofag alveoli.

\section{METODE}

Penelitian ini adalah studi eksperimental dengan model rancangan acak lengkap menggunakan dua perlakuan yaitu paparan asap rokok dan dosis ekstrak jinten hitam.

Hewan uji adalah tikus Rattus novergicus strain Wistar dewasa jantan usia 2,5 bulan - 3 bulan, berat badan 150-250 gram diperoleh dari Laboratorium Biokimia Universitas Airlangga. Aklimatisasi selama seminggu dengan akses bebas terhadap air dan pakan standar. Tikus dibagi menjadi 5 kelompok secara acak masing-masing kelompok 6 ekor. Terdiri dari kelompok kontrol negatif (tanpa dipapar asap rokok dan tanpa ekstrak jinten hitam), kelompok kontrol positif (dipapar asap rokok tanpa diberi ekstrak jinten hitam), kelompok A (dipapar asap rokok dan diberi ekstrak jinten hitam dosis $0.6 \mathrm{gr} / \mathrm{KgBB} / \mathrm{hr}$ ), kelompok B (dipapar asap rokok dan diberi ekstrak jinten hitam dosis $1.2 \mathrm{gr} / \mathrm{KgBB} / \mathrm{hr}$ ) dan kelompok C (dipapar asap rokok dan diberi ekstrak jinten hitam dosis $2.4 \mathrm{gr} / \mathrm{KgBB} / \mathrm{hr}$ ).

Pemberian ekstrak jinten hitam personde selama 3 bulan. Paparan asap rokok diberikan dengan dosis 2 batang rokok /hari. Satu batang rokok pagi dan satu batang rokok siang hari. Dipapar asap rokok dengan alat 'smoking pump' selama 3 bulan. Pada akhir masa perlakuan tikus dibunuh dengan cara dislokasi leher.

\section{Bahan ekstraksi}

Biji jinten hitam telah dideterminasi oleh Balai Materia Medica Batu Jawa Timur. Etanol $96 \%$ untuk ekstraksi didapatkan dari Laboratorium Farmakologi Universitas Brawijaya.

Biji jinten hitam tersebut diblender hingga halus kemudian direndam dalam etanol $96 \%$, digoyang menggunakan shacker selama 20 jam kemudian didiamkan selama 24 jam. Selanjutnya dievaporasi untuk meguapkan etanol sehingga tersisa minyak jinten hitam yang akan digunakan dalam penelitian.

\section{Bahan untuk Paparan Asap Rokok}

Rokok kretek tanpa filter merek tertentu yang diperoleh di pasaran.

\section{Bahan untuk pemeriksaan GSH}

Bahan pemeriksaan GSH (5-Sulfosalicylic acid dehydrate: MP.Biomedicals, Cat No. 160001) Sulfosalicylic acid $4 \%$, sodium buffer phosfat $(0,1 \mathrm{mM}, \mathrm{pH} 7,4)$ dan DTNB (5,5-Dithiobis - (2-Nitrobenzoic acid): ICN Biomedicals, Inc, Cat. No. 150126).

\section{Bahan Pemeriksaan MDA}

Larutan TRIS $10 \mathrm{mM}, \mathrm{HCl}$, TCA MERCK K35800007 611, dan Na-thio (NaOH - TBA: SIGMA, T- 5500).

\section{Bahan Pemeriksaan Fungsi fagositosis dan Fungsi Sekresi ROI Makrofag alveoli}

Superoxide dismutase (SOD) dari Sigma (S-2515), Phorbol Myrystate acid (PMA) dari sigma (P-8139), Neutral red solution dari Sigma (N-2889). Partikel Lateks dari TBA Sigma (S-2515): T-5500. Cat Giemsa dan cat Wright dari Laboratorium Analitika Surabaya.

\section{Prosedur Analisa}

Kadar GSH diukur dengan metode Ellman yaitu berdasar reaksinya dengan dTNB (5-5' dithion bis-2nitrobenzoic acid) (Gupta, 2004).

Kadar MDA diukur berdasar reaksi MDA dengan thiobarbituric acid berdasar metode Uchiyama dan Mihara (Uchiyama, 1978) yang dikembangkan di Laboratorium Farmakologi Fakultas Kedokteran Universitas Brawijaya Malang.

Makrofag alveoli diperoleh dengan cara lavase bronkoalveolar dan dikultur menurut Lewis (1985) (10). Jumlah makrofag alveoli dihitung dari hemositometer dan hapusan cairan lavase bronkoalveolar dengan metode hitung jenis sel. Dengan metode hitung jenis sel, jumlah makrofag alveoli merupakan proporsi antara sel makrofag dengan sel lekosit yang lain. Dilihat dengan mikroskop perbesaran 40 kali.

Pengukuran fungsi sekresi ROI makrofag dilakukan dengan metode NBT. Sedangkan fungsi fagositosis 
berdasarkan uji kemampuan fagositosis nonspesifik in vitro metode dari Leijh (1986). Dilihat dengan mikroskop perbesaran 40 kali.

Persentase fungsi fagositosis dan fungsi sekresi ROI dihitung secara semikuantitatif dari 200 makrofag alveoli, berapa yang melakukan fagositosis serta berapa yang mensekresi ROI.

Analisa data menggunakan one way anova dan tukey HSD test.

\section{HASIL PENELITIAN}

Hasil pengukuran kadar GSH dan MDA jaringan paru dapat dilihat pada Tabel 1, Grafik 1 serta Grafik 2.

Hasil uji dengan analisa sidik ragam (one way anova) adalah bahwa kadar GSH antar kelompok terdapat perbedaan yang bermakna $(p=0,009)$. Analisa dengan menggunakan Tukey HSD test hasilnya adalah kadar GSH kontrol positif lebih rendah secara bermakna dibandingkan kadar GSH kontrol negatif $(p<0,05)$. Hal ini berarti bahwa paparan asap rokok secara kronis dapat menurunkan kadar GSH jaringan paru.

Pada kelompok yang diberi ekstrak jinten hitam, hanya kadar GSH kelompok A yang lebih rendah secara bermakna dengan kontrol negatif. Sedangkan kadar GSH kelompok $\mathrm{B}$ dan kelompok $\mathrm{C}$ tidak mempunyai perbedaan yang bermakna dengan kontrol negatif maupun kontrol positif $(p>0,05)$. Hal ini berarti bahwa pemberian ekstrak jinten hitam memberikan pengaruh berupa peningkatan kadar GSH jaringan paru hingga mendekati kadar GSH normal.

Pemberian ekstrak jinten hitam menyebabkan penurunan kadar MDA pada semua kelompok yang diberi ekstrak jinten hitam, tetapi hanya kelompok $C$ yang mempunyai kadar MDA lebih rendah secara bermakna terhadap kontrol positif $(p=0,009)$. Hasil ini membuktikan bahwa pemberian ekstrak jinten hitam dapat menurunkan kadar MDA jaringan paru tikus yang dipapar asap rokok kronis mendekati nilai normal.

Efek pemberian ekstrak jinten hitam terhadap hitung jenis sel lekosit dan jumlah makrofag alveoli dapat dilihat pada Tabel 2, Grafik 3, Grafik 4 dan Grafik 5. Gambar sel makrofag alveoli dari cairan lavase bronkoalveolar serta fungsi sekresi $\mathrm{ROI}$ dan fungsi fagositosis sel makrofag alveoli dapat dilihat pada Gambar 1 dan Gambar 2.

Tabel 1. Efek Berbagai Dosis Ekstrak Jinten Hitam terhadap Kadar GSH dan MDA jaringan paru tikus yang dipapar asap rokok kronis

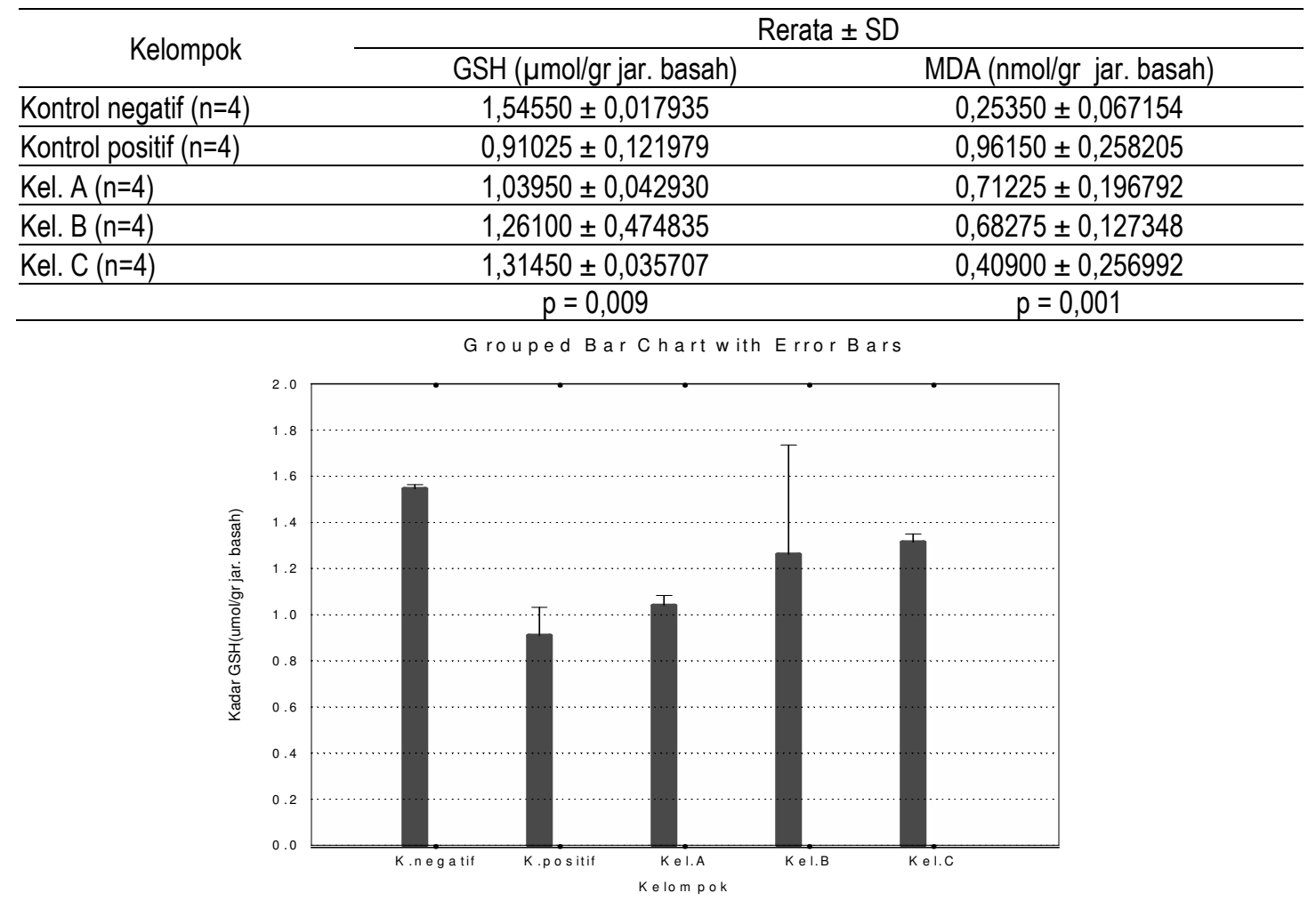

Grafik 1. Efek Berbagai Dosis Ekstrak Jinten Hitam terhadap Kadar GSH Jaringan Paru Tikus yang dipapar Asap Rokok Kronis $(p=0,009)$ 


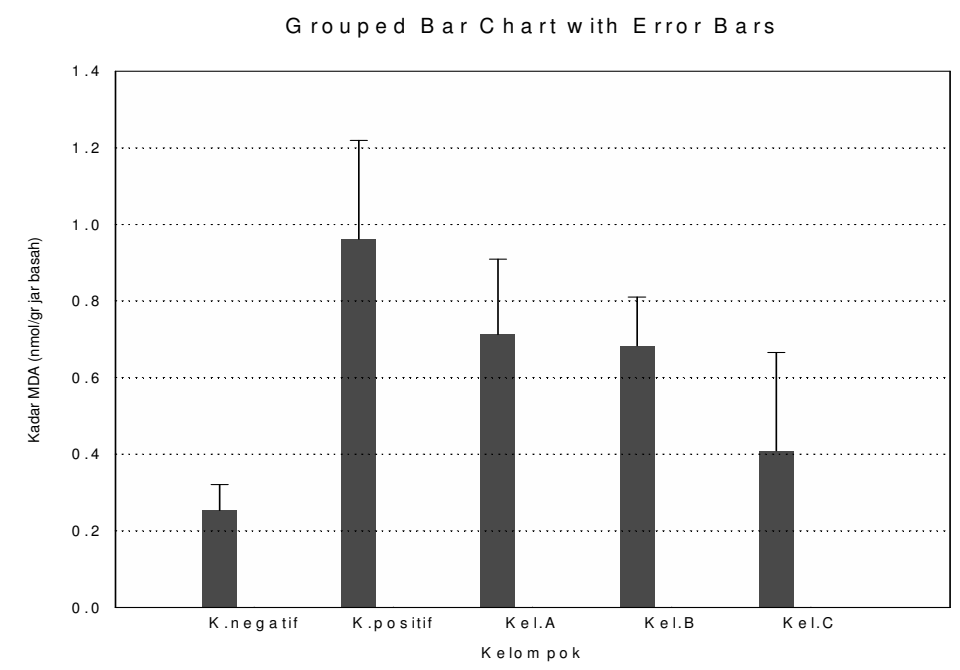

\section{Grafik 2. Efek Berbagai Dosis Ekstrak Jinten Hitam terhadap Kadar MDA Jaringan Paru Tikus yang Dipapar Asap Rokok Kronis $(p=0,001)$}

Keterangan :

1. Kontrol negatif : Tanpa paparan rokok dan tidak diberi ekstrak jinten hitam

2. Kontrol positif : Dipapar asap rokok kronis selama 3 bulan, tanpa diberi ekstrak jinten hitam

3. Kelompok A : Dipapar asap rokok kronis selama 3 bulan dan diberi ekstrak jinten hitam $0.6 \mathrm{gr} / \mathrm{KgBB} / \mathrm{hari}$.

4. Kelompok B : Dipapar asap rokok kronis selama 3 bulan dan diberi ekstrak jinten hitam $1.2 \mathrm{gr} / \mathrm{KgBB} / \mathrm{hari}$.

5. Kelompok $\mathrm{C}$ : Dipapar asap rokok kronis selama 3 bulan dan diberi ekstrak jinten hitam $2.4 \mathrm{gr} / \mathrm{KBB} / \mathrm{hari}$
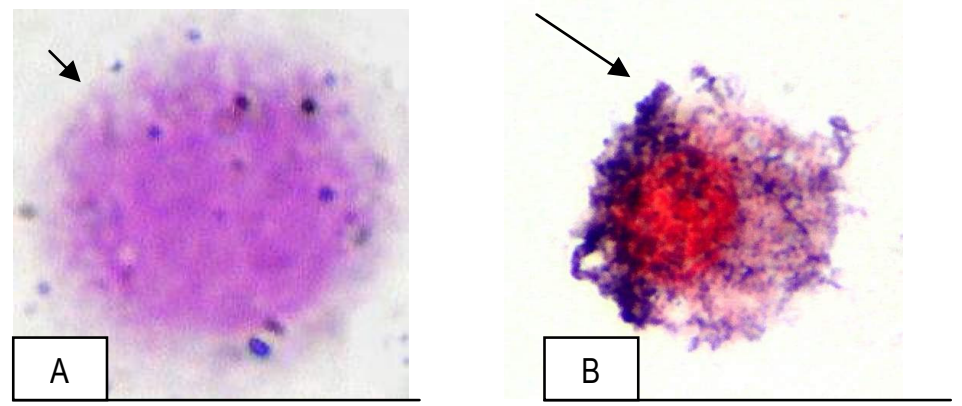

Keterangan:

Gambar 1: Makrofag Alveolar dari Cairan Lavase Bronkoalveolar Paru Tikus Wistar

A: Kelompok tanpa perlakuan asap rokok (pewarnaan Wright, 1000 kali)

$(\longrightarrow)$ : pseudopodi

Bintik-bintik biru keunguan merupakan artefak pengecatan yang sukar dibedakan dengan partikel yang difagosit oleh makrofag.

B: Kelompok yang dipapar asap rokok (pewarnaan neutral red, 1000 kali)

$(\longrightarrow)$ : Sekresi reactive oxygen intermediate (ROI) 

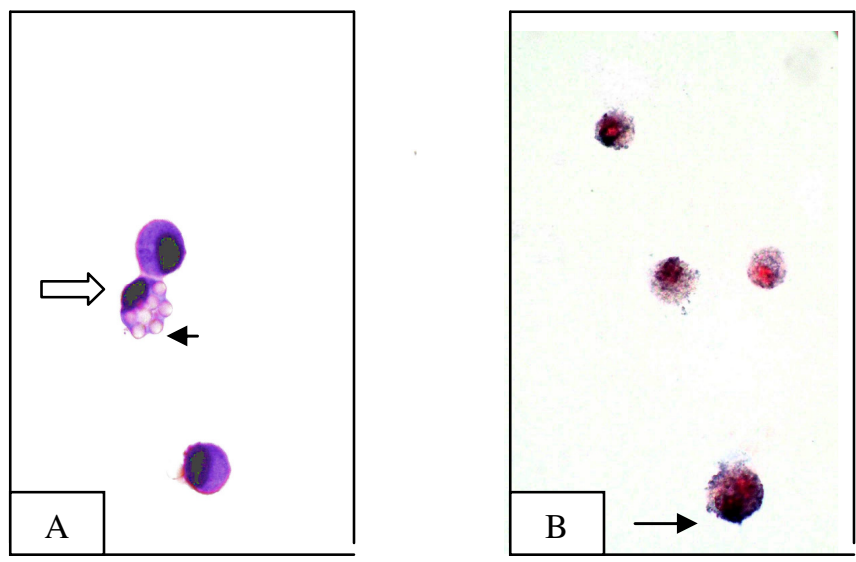

Gambar 2. Fungsi Makrofag Alveolar dari Cairan Lavase Bronkoalveolar Paru Tikus Wistar Kelompok yang dipapar Asap Rokok

Keterangan:

A: Fungsi fagositosis (pewarnaan Giemsa, perbesaran 400 kali)

$(\longrightarrow)$ : partikel-partikel lateks yang difagosit

$(\Rightarrow)$ : inti makrofag

B: Fungsi sekresi ROI (pewarnaan neutral red, perbesaran 400 kali)

$(\longrightarrow)$ : sekresi ROI

Tabel 2. Efek Berbagai Dosis Ekstrak Jinten Hitam terhadap Hitung Jenis Sel Lekosit serta Jumlah Sel Makrofag Alveoli (kamar hitung) Dari Cairan Lavase Bronkoalveolar Tikus yang Dipapar Asap Rokok Kronis

\begin{tabular}{cccc}
\hline \multirow{2}{*}{ Kelompok } & \multicolumn{3}{c}{ Rerata \pm SD } \\
\cline { 2 - 3 } & \multicolumn{2}{c}{ Hitung jenis } & \multirow{2}{*}{$\Sigma$ Sel Makrofag Alveoli $(\times 104 / \mathrm{ml})$} \\
\cline { 2 - 3 } & $95,2500 \pm 0,5000$ & $4,7500 \pm 0,5000$ & $113,5000 \pm 2,02132$ \\
\hline Kontrol negatif & $98,2500 \pm 0,5000$ & $1,7500 \pm 0,5000$ & $136,0000 \pm 1,41421$ \\
\hline Kontrol positif & $94,5000 \pm 0,57735$ & $5,5000 \pm 0,42265$ & $124,5000 \pm 2,12122$ \\
\hline Kel. A & $92,0000 \pm 0,81650$ & $8,0000 \pm 0,18450$ & $117,5000 \pm 2,12132$ \\
\hline Kel. B & $90,5000 \pm 1,29099$ & $9,5000 \pm 0,70901$ & $116,0000 \pm 1,21421$ \\
\hline Kel. C & $p=0,000$ & $p=0,000$ & $p=0,000$ \\
\hline & & &
\end{tabular}

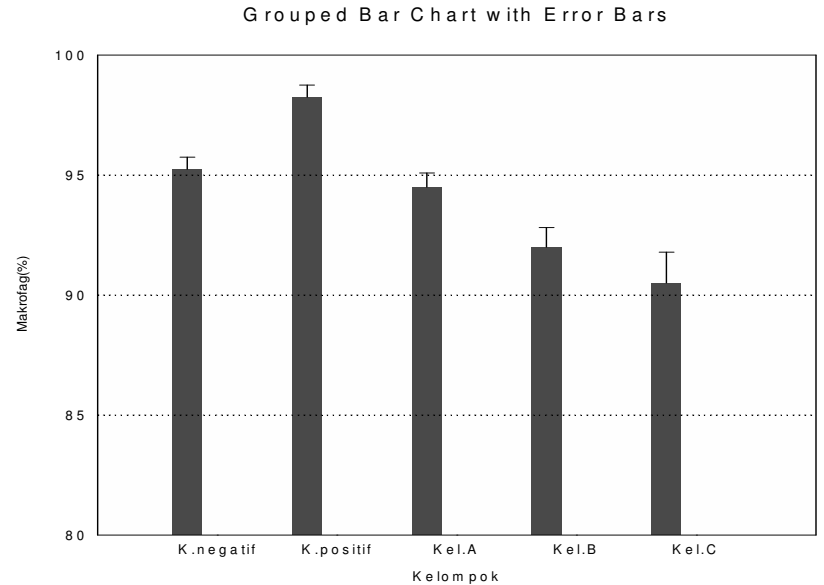

Grafik 3. Efek berbagai Dosis ekstrak Jinten Hitam terhadap Persentase sel Makrofag Alveoli (dari hitung jenis sel lekosit) dari Cairan Lavase Bronkoalveolar tikus yang dipapar asap rokok kronis $(p=0,000)$. 


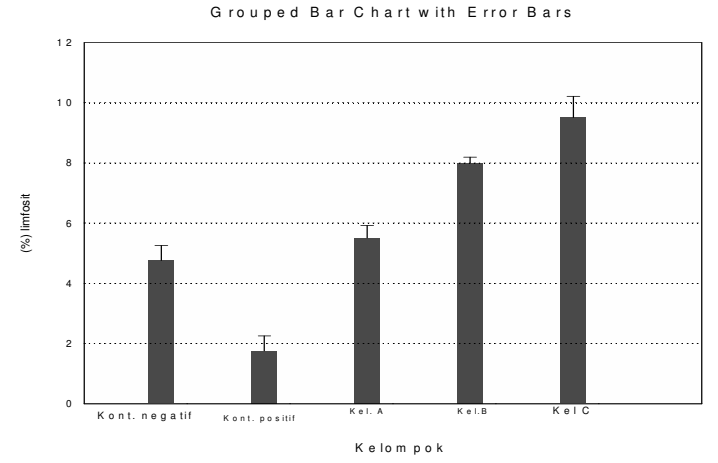

\section{Grafik 4. Efek berbagai Dosis ekstrak Jinten Hitam terhadap Persentase sel Limfosit (dari hitung jenis sel lekosit) dari Cairan Lavase Bronkoalveolar tikus yang dipapar asap rokok kronis $(p=0,000)$.}

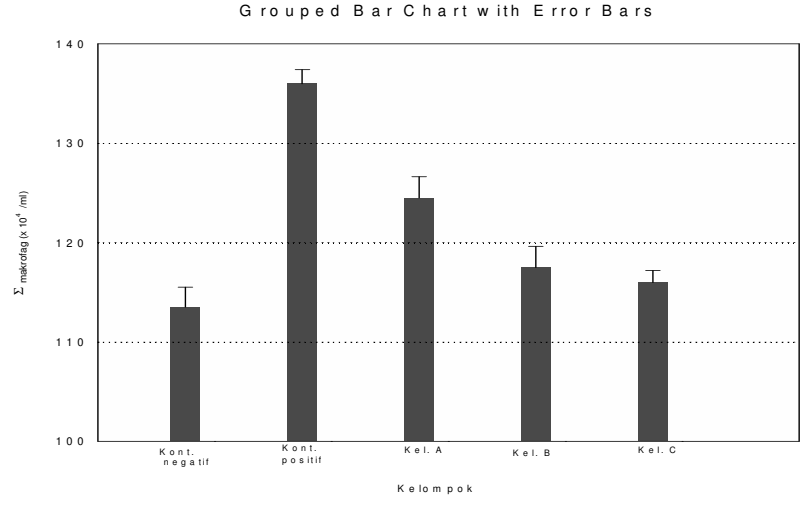

Grafik 5. Efek Berbagai Dosis Ekstrak Jinten Hitam terhadap Jumlah Sel Makrofag Alveoli (kamar hitung) dari Cairan Lavase Bronkoalveolar tikus yang dipapar asap rokok kronis $(p=0,000)$.

Keterangan:

1. Kontrol negatif $\quad$ :Tanpa paparan rokok dan tidak diberi ekstrak jinten hitam

2. Kontrol positif : Dipapar asap rokok kronis selama 3 bulan, tanpa diberi ekstrak jinten hitam

3. Kelompok A : Dipapar asap rokok kronis selama 3 bulan dan diberi ekstrak jinten hitam 0,6 gr/KgBB /hari.

4. Kelompok B : : Dipapar asap rokok kronis selama 3 bulan dan diberi ekstrak jinten hitam 1,2 gr/ KgBB/hari.

5. Kelompok C : Dipapar asap rokok kronis selama 3 bulan dan diberi ekstrak jinten hitam 2,4 gr/KBB/hari

Persentase makrofag alveoli dari semua kelompok yang mendapatkan ekstrak jinten hitam mempunyai nilai yang lebih rendah secara bermakna terhadap kontrol positif $(p=0,000)$. Hasil ini membuktikan bahwa ekstrak jinten hitam mampu menurunkan jumlah makrofag alveoli akibat paparan asap rokok kronis. Jumlah makrofag alveoli kelompok $A$ tidak berbeda bermakna terhadap kontrol negatif $(p=0,676)$. Jumlah makrofag alveoli kelompok $B$ lebih rendah secara bermakna terhadap kontrol negative $(\mathrm{p}$ $=0,000)$ dan terhadap kelompok $A(p=0,000)$. Jumlah makrofag alveoli kelompok $C$ juga lebih rendah secara bermakna terhadap kelompok $A(p=0,000)$ dan kontrol negatif $(p=0,000)$. Hal ini didukung pula dengan penurunan jumlah sel makrofag alveoli yang dihitung menggunakan kamar hitung Improve neubauer. Sebaliknya, persentase sel limfosit meningkat pada kelompok tikus yang diberi ekstrak jinten hitam.
Persentase makrofag alveoli yang mensekresi ROI dari semua kelompok yang diberi ekstrak jinten hitam juga lebih rendah secara bermakna dibanding kontrol positif $(p=$ 0,000 ). Kelompok A mempunyai persentase makrofag alveoli yang mensekresi ROI lebih tinggi secara bermakna terhadap kontrol negatif ( $p=0,001$ ), juga lebih tinggi secara bermakna terhadap kelompok $B(p=0.043)$ dan kelompok $C(p=0,013)$. Sedangkan kelompok B tidak berbeda secara bermakna terhadap kelompok $C(p=0,933)$ maupun kontrol negatif $(p=0,195)$. Kelompok $C$ tidak berbeda secara bermakna terhadap kontrol negatif $(p=0,519)$. Hal ini berarti bahwa ekstrak jinten hitam mampu menurunkan jumlah makrofag alveoli yang mensekresi ROI.

Persentase jumlah sel makrofag yang melakukan fagositosis dari seluruh kelompok yang mendapatkan ekstrak jinten hitam lebih rendah secara bermakna dari kontrol positif $(p=0,000)$. Pada kelompok-kelompok yang mendapatkan ekstrak jinten hitam tersebut, hanya kelompok 
$A$ dan kelompok $B$ yang mempunyai perbedaan yang bermakna $(p=0,000$ dan $p=0,026$ ) terhadap kontrol negatif. Sedangkan kelompok $C$ tidak mempunyai perbedaan yang bermakna dengan kontrol negatif $(p=$ 0,850 ). Kelompok $A$ juga mempunyai perbedaan yang bermakna dengan kelompok $B(p=0,002)$ dan kelompok $C$ $(p=0,000)$. Sedangkan kelompok $B$ tidak mempunyai perbedaan yang bermakna dengan kelompok $C(p=0,159)$. Hasil ini membuktikan bahwa ekstrak jinten hitam dapat menurunkan jumlah makrofag alveoli yang memfagosit lateks akibat paparan asap rokok kronis.

Tabel 3. Efek Berbagai Dosis Ekstrak Jinten Hitam terhadap Fungsi Sekresi ROI dan Fungsi Fagositosis dari Sel Makrofag Alveoli Paru yang Dipapar Asap Rokok Kronis

\begin{tabular}{lcc}
\hline \multirow{2}{*}{ Kelompok } & \multicolumn{2}{c}{ Rerata \pm SD } \\
\cline { 2 - 3 } & $(\%)$ Sekresi ROI & $(\%)$ Fagositosis \\
\hline Kontrol negatif & $8,6667 \pm 0,28868$ & $1,1250 \pm 0,47871$ \\
\hline Kontrol positif & $37,5000 \pm 4,33013$ & $32,8750 \pm 2,52900$ \\
\hline Kel. A & $21,1667 \pm 3,75278$ & $8,2500 \pm 0,64550$ \\
\hline Kel. B & $13,8333 \pm 1,25831$ & $4,1250 \pm 0,62915$ \\
\hline Kel. C & $12,1667 \pm 0,76376$ & $2,0000 \pm 0,40825$ \\
\hline & $p=0,000$ & $p=0,000$ \\
\hline
\end{tabular}

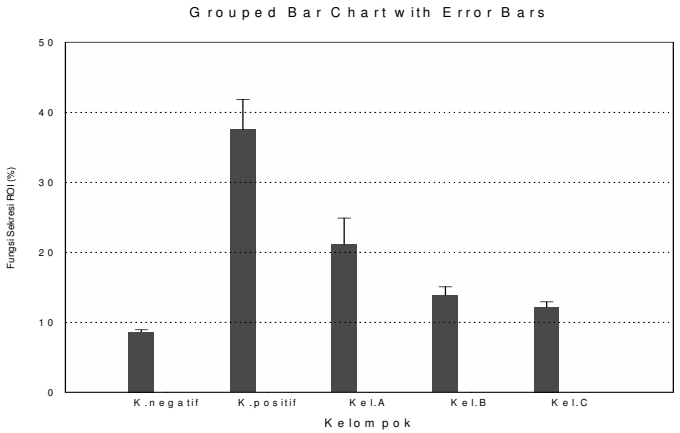

Grafik 6. Efek berbagai dosis ekstrak Jinten Hitam terhadap Fungsi Sekresi ROI Makrofag Alveoli dari Cairan Lavase Bronkoalveolar tikus yang dipapar Asap Rokok Kronis $(p=0,000)$.

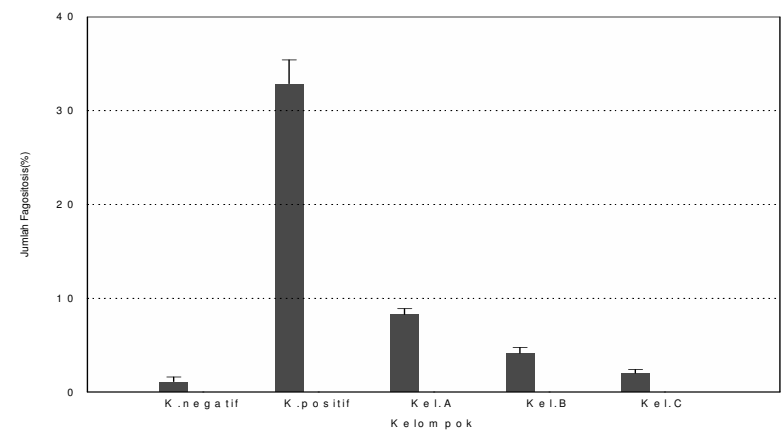

Grafik 7. Efek Berbagai Dosis Ekstrak Jinten Hitam terhadap Fungsi Fagositosis Sel Makrofag Alveoli dari Cairan Lavase Bronkoalveolar Tikus yang Dipapar Asap Rokok Kronis $(p=0,000)$

Keterangan :

1. Kontrol negatif : Tanpa paparan rokok dan tidak diberi ekstrak jinten hitam

2. Kontrol positif : Dipapar asap rokok kronis selama 3 bulan, tanpa diberi ekstrak jinten hitam

3. Kelompok A : Dipapar asap rokok kronis selama 3 bulan dan diberi ekstrak jinten hitam 0,6 gr/ $\mathrm{KgBB} / \mathrm{hari}$.

4. Kelompok B : Dipapar asap rokok kronis selama 3 bulan dan diberi ekstrak jinten hitam 1,2 gr/ $\mathrm{KgBB} / \mathrm{hari}$.

5. Kelompok C : Dipapar asap rokok kronis selama 3 bulan dan diberi ekstrak jinten hitam 2,4 gr/KBB/hari 


\section{DISKUSI}

Pada penelitian ini untuk mencegah kondisi stres oksidatif tersebut digunakan ekstrak jinten hitam berbagai dosis yaitu 0,6 gr/KgBB/hari, 1,2 gr/KgBB/hari dan 2,4 $\mathrm{gr} / \mathrm{KgBB} /$ hari selama tiga bulan.

Stres oksidatif yang ditandai dengan meningkatnya kadar peroksidasi lemak yaitu kadar MDA akibat paparan asap rokok kronis dapat diturunkan dengan pemberian ekstrak jinten hitam. Hal itu terbukti pada penelitian ini dimana kadar MDA jaringan paru pada semua kelompok yang dipapar asap rokok kronis dan mendapat ekstrak jinten hitam lebih rendah dibanding kelompok yang hanya dipapar asap rokok kronis $(0,96150 \pm 0,258205 \mathrm{nmol} / \mathrm{gr}$.jar) . Penurunan yang paling bermakna $(p=0,009)$ adalah terjadi pada kelompok $C$ yang mendapat dosis ekstrak jinten hitam 2,4 gr/KgBB/hari, dimana kadar MDA jaringan parunya menjadi sebesar $0,40900 \pm 0,256992 \mathrm{nmol} / \mathrm{gram}$ jaringan. Hasil ini menandakan adanya perbaikan ke arah kelompok kontrol negatif (normal) yang mempunyai kadar MDA jaringan 0,25350 $\pm 0,067154 \mathrm{nmol} / \mathrm{gr}$. jaringan.

Hasil ini didukung penelitian yang dilakukan oleh Prasiska (2004) tentang stress oksidatif di hepar akibat paparan asap rokok yang menemukan adanya penurunan secara bermakna kadar MDA jaringan hepar pada kelompok yang mendapat ekstrak jinten hitam. Penurunan kadar MDA yang terjadi bahkan melebihi kadar MDA jaringan hepar kelompok kontrol negatif (11).

Selain itu, penelitian yang dilakukan oleh Houghton dan kawan-kawan pada tahun 1995 menemukan adanya potensi antioksidan pada thymoquinone (zat aktif yang dikandung oleh jinten hitam) dan minyak jinten hitam. Aktivitas antioksidan kedua bahan tersebut ditentukan dengan kemampuannya menghambat peroksidasi nonenzimatis fosfolipid liposom otak sapi. Hasil lain penelitian tersebut adalah minyak jinten hitam lebih kuat dibanding thymoquinone menghambat kedua proses tersebut (8).

Kondisi stres oksidatif selain ditandai dengan peningkatan kadar MDA juga disertai menurunnya kadar antioksidan seperti GSH. Pada penelitian ini, akibat paparan asap rokok kronis terjadi penurunan kadar GSH jaringan paru pada kelompok yang hanya dipapar asap rokok $(0,91025 \pm 0,121979 \mu \mathrm{mol} / \mathrm{gr}$. jar). Dari hasil penelitian ini ternyata pemberian ekstrak jinten hitam mampu menahan laju penurunan kadar GSH tersebut. Hal itu terbukti pada semua kelompok yang selain dipapar asap rokok juga diberi ekstrak jinten hitam. Kadar GSH semua kelompok yang mendapat ekstrak jinten hitam tersebut lebih tinggi dibanding kelompok tikus yang hanya dipapar asap rokok kronis. Kadar GSH tertinggi pada kelompok tersebut adalah pada kelompok $\mathrm{C}$ yang mendapat dosis ekstrak jinten hitam 2,4 gr/kgBB/hari, yaitu sebesar 1,31450 $\pm 0,035707 \mu \mathrm{mol} /$ gr. jaringan. Nilai ini mendekati kadar GSH kontrol negatif (normal) yang mempunyai nilai $1,54550 \pm 0,017935 \mu \mathrm{mol} /$ gr. jaringan.

Hasil ini didukung oleh penelitian yang dilakukan oleh Shoker dkk tentang peranan thymoquinone murni terhadap penanganan penyakit experimental allergic encephalomyelitis pada tikus. Hasilnya adalah thymoquinone tersebut dapat menghambat stres oksidatif yang terjadi pada penyakit experimental allergic encephalomyelitis yang ditandai dengan meningkatnya kadar GSH di jaringan medulla spinalis tikus yang mendapat thymoquinone (12). Selain itu, El Dakhakhny (2000) pada penelitiannya tentang kemampuan proteksi jinten hitam terhadap ulkus lambung tikus yang dinduksi ethanol, mendapatkan hasil adanya peningkatan yang bermakna kadar GSH dan penurunan kadar histamin di dalam sekresi getah lambung pada kelompok yang mendapatkan ekstrak jinten hitam (9).

Peranan antioksidan sebagai proteksi terhadap stres oksidatif pada makrofag alveoli akibat paparan asap rokok kronis sebelumnya telah diteliti oleh beberapa orang. Salah satunya adalah Subandi (1998) yang meneliti tentang pengaruh pemberian vitamin $\mathrm{C}$ terhadar kadar SOD jaringan paru, jumlah serta fungsi makrofag alveoli (fungsi fagositosis dan fungsi sekresi ROI) paru tikus wistar yang dipapar asap rokok kronis. Hasil penelitian tersebut diantaranya adalah akibat paparan asap rokok kronis, jumlah dan fungsi makrofag alveoli meningkat, tetapi pada kelompok yang diberi vitamin $\mathrm{C}$ terjadi penurunan jumlah dan fungsi makrofag alveoli dibanding yang hanya dipapar asap rokok kronis (6).

Pada penelitian ini didapatkan hasil yang serupa, yaitu pengaruh stres oksidatif akibat paparan asap rokok dapat dicegah oleh pemberian ekstrak jinten hitam. Hal ini dapat dilihat pada hasil penelitian ini. Jumlah makrofag alveoli pada semua kelompok yang mendapat ekstrak jinten hitam lebih rendah secara bermakna terhadap kelompok yang hanya dipapar asap rokok kronis $(p=0,000)$. Jumlah makrofag kelompok yang hanya dipapar asap rokok sebesar $\quad 98,2500 \pm 0,5000 \%$. Sedangkan jumlah makrofag pada kelompok yang mendapat ekstrak jinten hitam terendah terdapat pada kelompok $C$ yang mendapat dosis ekstrak jinten hitam 2,4 gr/KgBB/hari, yakni sebesar $90,5000 \pm 1,29099 \%$. Jumlah makrofag alveoli pada kelompok $\mathrm{C}$ tersebut juga lebih rendah daripada jumlah makrofag alveoli kelompok kontrol negatif (normal) yang sebesar $95,2500 \pm 0,5000 \%$. Adanya penurunan ini sama dengan penelitian yang dilakukan oleh Zaoui (2002) tentang efek minyak jinten hitam terhadap homeostasis darah di tikus. Homeostasis darah tikus yang diukur adalah kadar kolesterol dan trigliserida serum, kadar glukosa darah, hitung lekosit serta jumlah platelet. Salah satu hasil penelitian tersebut adalah hitung lekosit darah yang 
menurun secara bermakna pada kelompok yang mendapat minyak jinten hitam (13).

Hal yang sama ditemukan pada jumlah makrofag yang menfagosit partikel lateks serta jumlah makrofag alveoli yang mensekresi ROI. Jumlah makrofag yang memfagosit partikel lateks menandakan fungsi fagositosis dari makrofag alveoli. Sebagai dampak dari pemberian ekstrak jinten hitam, jumlah sel makrofag yang memfagosit partikel lateks juga menurun. Hal itu dapat dilihat dari jumlah sel yang memfagosit partikel lateks pada kelompok yang hanya dipapar asap rokok kronis dibandingkan dengan semua kelompok yang mendapat ekstrak jinten hitam. Pada kelompok yang hanya dipapar asap rokok jumlah makrofag yang memfagosit partikel lateks adalah $32,8750 \pm 2,52900 \%$. Sedangkan pada kelompok yang mendapat ekstrak jinten hitam terdapat penurunan yang bermakna $(p=0,000)$ dan nilai paling rendah terdapat pada kelompok $C$ yang mendapat dosis ekstrak jinten hitam 2,4 $\mathrm{gr} / \mathrm{KgBB} /$ hari, yaitu sebesar $2,0000 \pm 0,40825 \%$. Nilai ini mendekati nilai pada kelompok kontrol negatif (normal) yaitu $1,125 \pm 0,47871 \%$. Hal ini menandakan adanya perbaikan ke arah normal pada kelompok yang diberi ekstrak jinten hitam.

Penurunan kemampuan fagositosis dari sel makrofag alveolar akibat pemberian jinten hitam tersebut sejalan dengan penelitian yang dilakukan oleh Haq dan kawan tentang efek jinten hitam pada limfosit manusia dan aktivitas fagositosis dari sel polimorfonuklear. Pada penelitian tersebut didapatkan hasil bahwa pemberian jinten hitam menekan leucocyte chemiluminescence activity yang distimulasi menggunakan phorbol myristate acetate dan zymosan (14).

Jumlah sel makrofag alveoli yang mensekresi ROI menunjukkan fungsi sekresi ROI makrofag alveoli. Pada penelitian ini pemberian ekstrak jinten hitam dapat menurunkan jumlah makrofag alveoli yang mensekresi ROI akibat paparan asap rokok kronis. Hal ini dapat dilihat dari jumlah makrofag alveoli yang mensekresi ROI pada kelompok yang hanya dipapar asap rokok kronis dan kelompok yang juga diberi ekstrak jinten hitam. Pada kelompok yang hanya dipapar asap rokok kronis, jumlah makrofag yang mensekresi ROI sebesar 37,5000 \pm $4,33013 \%$. Nilai tersebut menurun secara bermakna $(p=0,000)$ pada semua kelompok yang mendapat ekstrak jinten hitam. Pada kelompok yang mendapat ekstrak jinten hitam nilai terendah ada pada kelompok $C$ yang mendapat dosis ekstrak jinten hitam 2,4 gr / KgBB / hari, yakni sebesar $12,1667 \pm 0,76376 \%$. Nilai ini mendekati nilai dari kelompok kontrol negatif (normal) yang sebesar 8,6667 \pm $0,28868 \%$. Hal ini berarti ada perbaikan menuju ke arah normal.

Hasil-hasil penelitian tersebut menandakan adanya potensi antioksidan di dalam ekstrak jinten hitam. Berdasar uraian tersebut di atas, diduga kuat bahwa zat aktif yang dikandung oleh ekstrak jinten hitam yang berperan sebagai antioksidan adalah thymoquinone. Adapun mekanisme thymoquinone sebagai antioksidan masih belum jelas.

Burits dan Bucar (2000) menguji minyak esensial dari jinten hitam menggunakan metode kromatografi lapis tipis dua dimensi, mendapatkan bahwa kandungannya berupa thymoquinone, carvacrol, $t$-anethole dan 4-terpineol mempunyai kemampuan radical scavenging (7). Komponen yang dikandung oleh jinten hitam tersebut mempunyai kemampuan $\mathrm{OH}$ radical scavenging yang efektif pada peroksidasi lipid nonenzimatis dan degradasi deoxyribose. Sementara itu, Badary dan kawan (2003) melakukan penelitian untuk menguji efek antioksidan thymoquinone dan tert-butylhydroquinone (TBHQ) secara in vitro. Kedua bahan tersebut terbukti mampu menghambat peroksidasi lipid mikrosomal. Selain itu terbukti bahwa tyhmoquinone lebih aktif berperan sebagai superoxide anion scavenger daripada TBHQ (15).

Sedangkan pada penelitian ini dapat diduga bahwa mekanisme thymoquinone sebagai antioksidan adalah sebagai superoxide anion scavenger. Dugaan ini didasarkan pada beberapa hal. Pertama, Okbi dan kawankawan melakukan penelitian tentang pengaruh suplemen minyak jinten hitam terhadap aktivitas penyakit dan status antioksidan pada pasien rheumatoid arthritis di Mesir. Status antioksidan yang diperiksa adalah aktivitas superoxide dismutase (SOD) eritrosit. Hasilnya adalah bahwa aktivitas SOD pada eritrosit menurun secara bermakna $(p<0.005)$ setelah diberi minyak jinten hitam (16). Kedua, Radikal bebas yang dikandung oleh asap rokok terdapat di fase gas dan fase tar. Radikal bebas dalam fase gas sebanyak $10^{14}$ molekul tiap kali hisap, terutama dalam bentuk alkil dan peroksil. Sebagian besar radikal bebas di fase gas tersebut berumur pendek dan segera dilenyapkan di epithelial lining fluid (ELF) yang melapisi saluran nafas bagian distal. Di dalam fase tar, radikal bebas yang dikandungnya lebih stabil dan sebagian besar adalah organik seperti radikal semiquinone. Radikal semiquinone ini dapat bereaksi dengan oksigen yang menghasilkan superoksid. Reaksi redoks yang terjadi inilah yang memproduksi ROS dalam jangka waktu yang panjang (1). Ketiga, peningkatan fungsi sekresi ROI disebabkan karena asap rokok mengandung radikal bebas dalam jumlah yang sangat besar. Dalam satu kali hisap, terdapat $10^{14}$ molekul radikal bebas. Asap rokok mengandung berbagai jenis radikal bebas oksigen dan karbon (17). Meskipun kebanyakan radikal bebas tersebut berumur pendek, tetapi radikal bebas nitrogen dioksida dan radikal semiquinon dapat mencapai paru sehingga menyebabkan lonjakan respirasi atau respiratory burst di dalam sel makrofag (18). Lonjakan respirasi tersebut tidak tampak pada sel dalam keadaan tenang karena jalur metabolik ini 
dimaksudkan untuk menghasilkan bahan yang sangat mematikan terhadap bakteri dengan cara reduksi oksigen secara parsial. Lonjakan respirasi akan terjadi pada setiap gangguan terhadap membran makrofag (18).

Pada lonjakan respirasi akan terjadi peningkatan konsumsi oksigen dan diaktifkannya jalur pentosa (Hexose monophosphate shunt $=$ HMP shunt). Aktifnya HMP shunt tersebut menyebabkan NADPH banyak dihasilkan. Di dalam membran makrofag terdapat rantai transfer elektron yang mengandung suatu NADPH oksidase, yang merupakan suatu sistem kompleks yang terdiri dari flavoenzim. Apabila terdapat gangguan terhadap membran makrofag, misalnya akibat partikel-partikel atau karena radikal bebas yang terdapat di dalam asap rokok, maka NADPH oksidase ini menjadi aktif yang kemudian menyebabkan terjadi transfer elektron. Transfer elektron dari oksigen akan mengakibatkan reduksi sebuah elektron dari oksigen tersebut, sehingga terbentuk radikal anion superoksid $(18,19)$.

Berdasarkan tiga alasan tersebut di atas, maka dapat diduga bahwa ekstrak jinten hitam yang digunakan pada penelitian ini mengandung thymoquinone yang berperan sebagai superoxide anion scavenger, namun demikian untuk membuktikannya, masih diperlukan penelitian lebih lanjut tentang aktivitas SOD dengan desain penelitian yang sama dengan penelitian ini.

Dari uraian hasil penelitian di atas, hipotesa bahwa ekstrak jinten hitam mampu memberikan proteksi terhadap stres oksidatif di paru tikus akibat paparan asap rokok terbukti. Dengan demikian, penggunaan ekstrak jinten hitam sebagai obat secara tradisional dalam dosis tertentu dapat dibenarkan secara ilmiah meskipun masih diperlukan penelitian lebih lanjut mengenai penggunaannya pada manusia. Penelitian lanjutan yang dapat dilakukan adalah tentang dosis efektif, toksisitas dan efek sampingnya pada manusia.

\section{KESIMPULAN}

1. Ekstrak jinten hitam yang digunakan pada penelitian ini mampu memberikan proteksi terhadap stres oksidatif di paru tikus akibat paparan asap rokok kronis. Hal itu terbukti dengan adanya peningkatan antioksidan enzimatis GSH dan menurunnya MDA jaringan paru tikus wistar pada kelompok yang mendapat ekstrak jinten hitam.

2. Pengaruh pemberian ekstrak jinten hitam terhadap sel makrofag alveoli paru tikus wistar yang dipapar asap rokok kronis menyebabkan penurunan jumlah dan fungsi sekresi serta fungsi fagositosis dari sel makrofag alveoli tersebut. Hasil ini di satu sisi menguntungkan karena dapat mengurangi aktivitas radikal bebas, tetapi di sisi yang lain dapat merugikan karena dapat mempengaruhi respon imun di paru mengingat peranan makrofag dalam respon imun. Hal ini membutuhkan penelitian yang lebih dalam lagi.

3. Mekanisme biji jinten hitam atau zat aktif di dalamnya sebagai antioksidan belum jelas, sehingga perlu penelitian lebih lanjut untuk mengetahuinya.

\section{SARAN}

Dari hasil penelitian ini dapat disarankan beberapa hal:

1. Untuk mengetahui mekanisme antioksidan jinten hitam perlu diteliti kadar SOD paru.

2. Sebelum digunakan untuk kepentingan penanganan penyakit PPOM terlebih dahulu dikaji tentang toksisitas dan efek sampingnya.

3. Penyebab PPOM bersifat multikausal. Di dalamnya terlibat beberapa faktor seperti genetik, imunologi, ketidakseimbangan oksidan-antioksidan dan ketidakseimbangan protease-antiprotease. Pada penelitian ini hanya dibatasi pada ketidakseimbangan oksidanantioksidan, sehingga masih perlu penelitian yang lebih lanjut tentang kaitan antara ketidakseimbangan oksidan-antioksidan dengan penyebab-penyebab PPOM yang lain.

\section{DAFTAR KEPUSTAKAAN}

1. MacNee W. Rahman I. Oxidant and Antioxidant as Theurapetic Targets in Chronic Obstructive Pulmonary Disease. American Journal Respiration Critical Care Med 1999; 160: S58 - S65

2. Rennard SI. Inflammation and Repair Processes in Chronic Obstructive Pulmonary Disease. American Journal Respiratory Critical Care Med 1999; 160: S12 - S16

3. Aldonyte R, Jannson L, Pitulainen E, Janciauskiene S. Circulating Monocytes from Healthy Individuals and COPD patients. Biomed Central, Respiratory Research 2003; 4: 1 - 8

4. Halliwell B, Gutteridge J. Free Radical in Biology and Medicine. Oxford: Oxford Science Publicatio 1999; $442-467$

5. Aoshiba K, Nagai A. Oxidative Stress, Cell Death, and Other Damage to Alveolar Epithelial Cells Induced by Cigarette Smoke, Tobacco Induced Disease. 2003; 1(3): 219 - 226

6. Subandi. Efek Antioksidan (Vitamin C) terhadap Jumlah Fungsi Makrofag Alveoli serta Kadar SOD Jaringan Paru Tikus yang Dipapar dengan Asap Rokok Kronis. [Tesis]. Malang: Program Pascasarjana Universitas Brawijaya. 1998. 
7. Burist M, Bucar F. Antioxidant Activity of Nigella sativa Essential Oil. Abstract of Phytotherapy 2000; 14(5): $323-328$.

8. Houghton PJ, Zarka R. De Las Heras B, Hoult JR. Fixed Oil of Nigella sativa and Derived Thymoquinone Inhibit Eicosanoid Generation in Leucocytes and Membrane Lipid Peroxidation. Abstract Planta Med. 1995; 61(1): 33 -36.

9. El Dakhakhny M, Barakat M, El Halim MA, Aly SM. Effects of Nigella sativa oil on Gastric Secretion and Ethanol Induced Ulcer in Rats. Abstract of Journal Ethnopharmacology 2000; 72 (1-2): 299 - 304.

10. Lewis JG. Isolation of Alveolar Macrophage, Peritoneal Macrophage and kuppfer Cell. Methods in Immunotoxicology9burleson G.R et al eds). New York: Wiley-Liss Inc.Pub; 1995; 2: 15 - 26.

11. Prasiska OT. Pengaruh Pemberian Ekstrak Jinten Hitam (Nigella sativa) terhadap Kadar Malondialdehide Hepar Tikus Wistar yang Dipapar Asap Rokok Kronis. [Skripsi]. Malang: Fakultas Kedokteran Brawijaya. 2004.

12. Shoker A, Mohamed A. Improvement of Experimental Allergic Encephalitis (EAE) by Thymoquinone; an Oxidative Stress Inhibitor. Abstract of Biomed Science Instrumen 2003; 39: 440 - 445.

13. Zaoui A, Cherrah Y, Alaoui K, Mahassine N, Amarouch H, Hassar M. Effects of Nigella sativa Oil on Blood Homeostasis in Rat. Journal of Ethnopharmacology 2002; 79(1): 23-26.

14. Haq A, Abdullatif M, Lobo PI, Khabar KS, Sheth KV, Al-Sedairy ST. Nigella sativa: Effect on Human Lymphocytes and Polymorphonuclear Leucocyte Phagocytic Activity. Immunopharmacology 1995; 30(2):147-155.

15. Badary OA, Taha RA, Gamal el Din AM, Abdel Wahab. Thymoquinone is a Potent Superoxide Anion Scavenger. Abstract of Drug Chemical Toxicology 2003; 26(2): 87 - 98.

16. Al-Okbi SY, Ammar NM, Soroor KHA, Mohamed DA. Impact of Natural Oils Supplememnts on Disease Activity and Antioxidant State of Egyptian Patient with Rheumatoid Arthritis. Medical Journal of Islamic Academy of Sciences 2000; 134: 161 - 171.

17. Church DF and Pryor WA. Free Radical Chemistry of Cigarette Smoke and its Toxicological Implications. Environtmental Health Perspect 1985; 64: $111-126$.

18. Subowo. Imunobiologi. Penerbit Angkasa. 1993; 35 - 64

19. Favier AE. How to Demonstrate the Occurance of an Oxidative Stress in Human? In: Analisis of Free Radical in Biological System. Switzerland: Birlauser Verlaga; 1995; 102-110. 
